\title{
MENINGKATKAN HASIL BELAJAR SISWA DENGAN \\ MENGGUNAKAN METODE DISKUSI PADA MATA \\ PELAJARAN PKN DI KELAS V SDN NO. 067252 \\ MEDAN DELI
}

\author{
Herawati Bukit \\ Dosen Jurusan PPSD Prodi PGSD FIP UNIMED \\ Surel : herawatibukit@gmail.com
}

\begin{abstract}
ABSTRAK
Penelitian ini dilaksanakan dengan jumlah siswa sebanyak 29 orang siswa terdiri dari 12 orang laki-laki dan 17 orang perempuan. Objek dalam penelitian ini adalah untuk meningkatkan hasil belajar siswa pada pokok bahasan menghargai keputusan bersama. Hasil penelitian menunjukkan tingkat ketuntasan belajar siswa pada tes awal nilai rata-rata 47,24 dengan ketuntasan $20,68 \%$ atau 6 orang siswa, pada saat post tes I nilai rata-rata siswa $64,48 \%$ dengan ketuntasan $55,17 \%$ kemudian post tes II nilai rata-rata siswa 80,34 dengan ketuntasan belajar $93,10 \%$. Berarti hasil yang diperoleh siswa pada post tes II sudah mencapai tingkat ketuntasan secara klasikal. Ternyata dengan menggunakan metode diskusi siswa di Kelas V SDN No. 067252 Medan Deli dapat meningkatkan hasil belajar siswa.
\end{abstract}

Kata Kunci : Hasil Belajar, Diskusi, Pkn

\section{PENDAHULUAN}

Sekolah merupakan lembaga pendidikan untuk melaksanakan kegiatan belajar mengajar. Sekolah mempunyai tugas untuk menyiapkan anak didik menjadi anggota atau warga masyarakat yang sesuai dengan cita-cita, harapan dan nilainilai yang dianut serta dijunjung tinggi oleh masyarakat. Perkembangan dan kemajuan di suatu daerah sangat bergantung pada kualitas setiap individu yang tinggal di daerah tersebut. Semakin bagus kualitas setiap individu maka semakin bagus pula perkembangan dan kemajuan yang terjadi di daerah tersebut. Oleh karena itu, pendidikan sangat dibutuhkan oleh setiap individu baik anak-anak, dewasa, maupun orang tua memerlukan pendidikan karena pendidikan adalah suatu aktivitas yang dibangun untuk membentuk kualitas individu melaluai proses belajar. Sejak dini anak-anak membutuhkan pendidikan agar kelak dewasa menjadi anak yang berguna baik bagi bangsa, agama, maupun masyarakat. Di rumah anak-anak menerima pendidikan dari orang tuanya, sedangkan di sekolah anak-anak menerima pendidikan dari gurunya.

Di sekolah begitu banyak mata pelajaran yang diajarkan, salah satu diantara mata pelajaran tersebut adalah pendidikan kewarganegaraan. Pendidikan kewarganegaraan mengajarkan siswa tentang moral, saling tolong menolong, bekerja 
sama, toleransi, menghargai keputusan bersama dan masih banyak lagi yang dapat diperoleh siswa dalam belajar pendidikan kewarganegaraan. Asep Hernawan (2007:825) Mengemukakan bahwa "Pendidikan Kewarganegaraan merupakan usaha untuk membekali siswa dengan pengetahuan dan kemampuan dasar berkenaan dengan hubungan antara warga negara dengan Negara, serta pendidikan pendahuluan bela Negara agar menjadi warga Negara yang dapat diandalkan oleh bangsa dan Negara". Oleh karena itu, guru harus dapat mengajarkan pelajaran pendidikan kewarganegaraan kepada siswa dengan baik dan dapat menyesuaikan materi pelajaran dengan metode yang digunakan agar siswa tidak merasa bosan dalam mengikuti proses pembelajaran. Dalam proses belajar mengajar, guru sering menggunakan metode ceramah saja dimana guru yang selalu aktif dalam menyampaikan informasi bagi siswa, sehingga masih banyak siswa yang belum dapat memahami materi pelajaran dengan benar. Dalam pengamatan yang telah saya lakukan yaitu jumlah siswa 29 orang, terdiri dari laki-laki 12 orang dan perempuan 17 orang terdapat 20 orang siswa yang masih belum memahami materi dengan baik dalam pembelajaran PKn dan siswa akhirnya menjadi pasif karena hanya menerima informasi saja.

Hasil belajar siswa dipengaruhi oleh banyak faktor, salah satu faktor tersebut adalah guru. Oleh karena itu, guru harus dapat memilih metode yang sesuai dengan materi yang akan diajarkan agar tujuan pengajaran yang diinginkan dapat tercapai dan siswa dapat lebih aktif serta terlibat pada saat proses belajar mengajar berlangsung, karena kesalahan dalam memilih metode pembelajaran maka akan mengakibatkan siswa kurang aktif dalam belajar. Pokok bahasan keputusan bersama dalam pelajaran pendidikan kewarganegaraan sagat cocok menggunakan metode diskusi, karena dapat melatih siswa berbicara, berani bertanya, berani mengeluarkan pendapat dan mengambil keputusan serta menghagai keputusan yang diberikan oleh temannya.

Selain faktor guru, faktor yang lain yang menentukan hasil belajar siswa adalah motivasi siswa itu sendiri untuk berprestasi. Sering dijumpai siswa yang memiliki intelegensi yang tinggi tetapi hasil belajar yang dicapainya rendah, ini disebabkan karena kurangnya motivasi dalam diri siswa itu sendiri untuk berprestasi. Siswa akan belajar dengan sungguh-sungguh tanpa dipaksa, bila memiliki motivasi belajar yang besar.

$$
\text { Pada pengamatan yang }
$$
dilakukan di SDN No. 067252 Medan Deli khususnya kelas V motivasi belajar setiap siswa tergolong rendah, hal ini dapat terlihat dari keinginan setiap siswa mengikuti pembelajaran tidak serius, siswa merasa jenuh dalam proses belajar mengajar, sehingga siswa 
tidak memperhatikan guru pada saat menyampaikan informasi.

Apabila secara terus menerus guru selalu menggunakan metode ceramah, tanya jawab, ataupun penugasan tanpa menyesuaikan dengan materi yang akan diajarkan maka siswa akan merasa bosan dan jenuh dalam mengikuti proses belajar mengajar. Selain itu, kemungkinan banyak siswa yang kurang aktif dalam proses pembelajaran, dan banyak siswa yang tidak berani dalam bertanya maupun menjawab pertanyaan yang diajukan oleh guru.

Beranjak dari masalahmasalah yang telah diungkapkan di atas, maka perlu dipikirkan cara dan strategi untuk mengatasi permasalahan yang ada. Penggunaan metode yang sesuai merupakan salah satu upaya untuk meningkatkan hasil belajar siswa. Untuk itu dalam menyajikan materi yang berjudul keputusan bersama pada pelajaran Pendidikan Kewarganegaraan peneliti menggunakan metode diskusi. Tujuannya adalah agar melatih siswa dalam berbicara seperti memberikan ataupun mengajukan pendapat pada saat proses belajar mengajar berlangsung. Selain itu melatih siswa agar dapat menghargai pendapat yang telah diberikan oleh temannya walaupun belum tentu pendapat yang diberikan tersebut benar. J. Hasibuan, (1993:20) menyatakan bahwa "Metode Diskusi adalah suatu cara penyajian bahan pelajaran dimana guru memberi kesempatan kepada para siswa (kelompok-kelompok siswa) untuk mengadakan perbincangan ilmiah guna mengumpulkan pendapat, membuat kesimpulan, atau menyusun berbagai alternatif pemecahan atas suatu masalah.

Berdasarkan latar belakang masalah yang telah diuraikan di atas, maka dapat diidentifikasi beberapa permasalahan dalam penelitian ini yaitu :

1. Rendahnya hasil belajar siswa pada mata pelajaran Pendidikan Kewarganegaraan.

2. Metode pengajaran pada pelajaran Pendidikan

Kewarganegaraan yang digunakan guru belum sesuai dengan materi pelajaran.

3. Siswa masih kurang aktif dalam mengikuti pembelajaran Pendidikan Kewarganegaraan. Mengingat keterbatasan waktu, dana dan untuk mempermudah peneliti dalam melakukan penelitian maka peneliti merasa perlu membatasi masalah. Adapun batasan masalah tersebut adalah "Meningkatkan hasil belajar Siswa Dengan Menggunakan Metode Diskusi Pada Mata Pelajaran PKn Pokok Bahasan Menghargai Keputusan Bersama di Kelas V SDN No. 067252 Medan Deli.”

Berdasarkan pembatasan masalah di atas, maka rumusan masalah penelitian adalah "Apakah dengan menggunakan metode diskusi dapat meningkatkan hasil belajar Siswa pada Mata Pelajaran PKn pokok bahasan menghargai 
keputusan bersama di Kelas V SDN No. 067252 Medan Deli?"

Berdasarkan rumusan masalah di atas, maka tujuan penelitian ini adalah :

1. Untuk mengetahui peningkatan hasil belajar siswa, pada mata pelajaran PKn melalui penggunaan metode diskusi bagi siswa kelas V SDN No. 067252 Medan Deli.

2. Untuk meningkatkan pemahaman siswa terhadap mata pelajaran PKn khususnya pada materi pelajaran Menghargai keputusan Bersama.

3. Untuk meningkatkan keaktifan siswa selama pembelajaran PKn. Manfaat dari hasil penelitian ini adalah :

1. Bagi siswa, untuk meningkatkan hasil belajar, dan pemahaman siswa tentang pokok bahasan keputusan bersama dalam mata pelajaran pendidikan Kewarganegaraan.

2. Bagi guru, sebagai pedoman bagi guru dalam penggunaan metode diskusi yang mampu meningkatkan hasil belajar dan pemahaman siswa dalam mata pelajaran Pendidikan Kewarganegaraan.

3. Bagi kepala sekolah, sebagai masukan bagi kepala sekolah dalam meningkatkan hasil belajar siswa dan keterampilan guru dalam memilih metode pelajaran yang tepat.

4. Sebagai masukan bagi lembaga PGSD dan sebagai pertimbangan dalam penggunaan metode diskusi pada proses pembelajaran yang akan diterapkan oleh mahasiswa calon guru melalui program praktek lapangan (PPL) dalam mata pelajaran Pendidikan Kewarganegaraan.

5. Sebagai bahan pertimbangan dan sumbangan pemikiran bagi peneliti lain yang ingin mendalami lebih lanjut.

\section{METODE PENELITIAN \\ Jenis Penelitian}

Jenis penelitian yang dilakukan dalam penelitian ini adalah Penelitian Tindakan Kelas (PTK) atau dengan nama lain Classroom Action Research yaitu suatu model penelitian yang dikembangkan di kelas sesuai dengan kebutuhan atau permasalahan yang terjadi di dalam kelas tersebut. Sesuai dengan jenis penelitian ini, maka penelitian ini memiliki tahap-tahap penelitian berupa siklus.

\section{Lokasi dan Waktu Penelitian}

Penelitian ini dilakukan di SD Negeri 067252 Medan Deli Tahun Ajaran 2010/2011 dan direncanakan waktu penelitian pada semester II. Pelaksanaan penelitian ini akan dilaksanakan selama 3 bulan yaitu bulan April, Mei, dan Juni. Adapun yang menjadi subjek penelitian adalah siswa kelas V SD Negeri 067252 Medan Deli.

\section{Subjek dan Objek Penelitian}

Subjek penelitian tindakan kelas ini adalah siswa kelas V SD 
Negeri No. 067252 Medan Deli. TA 2010/2011 yang berjumlah 29 orang terdiri dari 17 orang Perempuanan 12 orang laki-laki.

\section{Teknik Pengumpulan Data}

Tekhnik yang digunakan dalam pengumpulan data pada penelitian ini adalah tes, dan observasi.

\section{a. Tes}

Tes dibuat untuk mengetahui
hasil belajar siswa setelah pembelajaran selesai dilakukan, yaitu pada akhir pengajaran yang bertujuan untuk mengetahui sampai dimana siswa memahami bahan pelajaran setelah mengalami suatu kegiatan belajar. Bentuk tes yang digunakan adalah pilihan berganda sebanyak 10 soal, masing-masing soal memiliki skor 10 jadi skor tertinggi adalah 100 .

\section{b. Observasi}

Yaitu mengamati keadaan yang ada di lapangan. Observasi dalam hal ini dilakukan pada saat proses pembelajaran berlangsung. Adapun yang dilakukan adalah mengamati aktifitas pembelajaran dengan menggunakan lembar observasi yang telah disiapkan. Observasi dilakukan untuk mengetahui kesesuaian tindakan dengan rencana yang telah disiapkan dan untuk mengetahui sejauhmana tindakan yang dilakukan dapat menghasilkan perubahan pada diri siswa, sedangkan bagi guru untuk mengetahui apakah guru mampu untuk meningkatkan hasil belajar siswa pada mata pelajaran PKn di Kelas V SD khususnya materi menghargai keputusan bersama.

\section{Desain dan Prosedur Penelitian}

Penelitian ini dilakukan dalam dua siklus yang di dalamnya terdapat empat tahapan utama kegiatan, yaitu perencanaan, tindakan, pengamatan, dan refleksi seperti yang telah digambarkan oleh Arikunto dkk (2008:16)

\section{Teknik Analisis Data}

Analisis data dalam rangka refleksi setelah implementasi suatu tindakan perbaikan, mencakup prosesdan dampak seperangkat tindakan perbaikan dalam suatu siklus PTK keseluruhan.

Hasil observasi akan
dianalisis oleh peneliti secara deskriptif. Untuk mengetahui hasil belajar siswa secara individu yang diperoleh dari hasil tes belajar dengan menggunakan rumus:

$$
P P H=\frac{B}{N} x 100
$$

(Suharsimi Arikunto, 2009:236) Dimana, $\mathrm{PPH}=$ Persentase penilaian hasil

$$
\begin{aligned}
& \mathrm{B}=\text { Skor yang } \\
& \text { diperoleh siswa } \\
& \mathrm{N}=\text { Skor Total }
\end{aligned}
$$

Target tuntas siswa secara individu apabila skor yang diperoleh siswa $\geq$ 65.

Untuk menentukan persentase hasil belajar siswa secara klasikal dengan rumus : 


$$
P=\frac{f}{n} x 100 \%
$$

(Rosmala Dewi, 2009:240)

Dimana, $\mathrm{P}=$ Jumlah persentase siswa yang mengalami perubahan $\mathrm{f}=$ Jumlah siswa yang tuntas $\mathrm{n}=$ Jumlah siswa keseluruhan suatu kelas dikatakan tuntas belajar apabila $\mathrm{P}>80 \%$

Untuk penilaian observasi dapat dilakukan dengan rumus sebagai berikut :

$$
P_{i}=\frac{f}{n} x 100 \%
$$

(Nana Sudjana, 2009:133)

$\mathrm{P}_{\mathrm{i}}=$ Persentase hasil pengamatan

$\mathrm{f}=$ Jumlah aspek yang diamati

$\mathrm{n}=$ Jumlah keseluruhan aspek yang diamati

secara individu dikatakan berhasil belajar jika $\mathrm{PPH} \geq 65$, suatu kelas dikatakan tuntas belajar apabila $\mathrm{P}$ $>80 \%$, dan untuk observasi $\mathrm{P}_{\mathrm{i}} \geq 3$

\section{HASIL PENELITIAN DAN PEMBAHASAN}

\section{Hasil Penelitian}

Dari hasil tes awal yang telah dilakukan, diperoleh nilai siswa sebagai berikut :

Tabel Hasil Belajar Siswa Pada Tes

\begin{tabular}{|c|c|c|c|c|c|}
\hline 7 & 07 & 7 & 70 & Tuntas & \\
\hline 8 & 08 & 5 & 50 & & $\begin{array}{c}\text { Tidak } \\
\text { Tuntas }\end{array}$ \\
\hline 9 & 09 & 7 & 70 & Tuntas & \\
\hline 10 & 10 & 5 & 50 & & $\begin{array}{c}\text { Tidak } \\
\text { Tuntas }\end{array}$ \\
\hline 11 & 11 & 5 & 50 & & $\begin{array}{c}\text { Tidak } \\
\text { Tuntas }\end{array}$ \\
\hline 12 & 12 & 4 & 40 & & $\begin{array}{c}\text { Tidak } \\
\text { Tuntas }\end{array}$ \\
\hline 13 & 13 & 3 & 30 & & $\begin{array}{c}\text { Tidak } \\
\text { Tuntas }\end{array}$ \\
\hline 14 & 14 & 3 & 30 & & $\begin{array}{c}\text { Tidak } \\
\text { Tuntas }\end{array}$ \\
\hline 15 & 15 & 2 & 20 & & $\begin{array}{c}\text { Tidak } \\
\text { Tuntas }\end{array}$ \\
\hline 16 & 16 & 4 & 40 & & $\begin{array}{c}\text { Tidak } \\
\text { Tuntas }\end{array}$ \\
\hline 17 & 17 & 7 & 70 & Tuntas & \\
\hline 18 & 18 & 6 & 60 & & $\begin{array}{c}\text { Tidak } \\
\text { Tuntas }\end{array}$ \\
\hline 19 & 19 & 2 & 20 & & $\begin{array}{c}\text { Tidak } \\
\text { Tuntas }\end{array}$ \\
\hline 20 & 20 & 6 & 60 & & $\begin{array}{c}\text { Tidak } \\
\text { Tuntas }\end{array}$ \\
\hline 21 & 21 & 2 & 20 & & $\begin{array}{c}\text { Tidak } \\
\text { Tuntas }\end{array}$ \\
\hline 22 & 22 & 5 & 50 & & $\begin{array}{c}\text { Tidak } \\
\text { Tuntas }\end{array}$ \\
\hline 23 & 23 & 3 & 30 & & $\begin{array}{c}\text { Tidak } \\
\text { Tuntas }\end{array}$ \\
\hline 24 & 24 & 6 & 60 & & $\begin{array}{c}\text { Tidak } \\
\text { Tuntas }\end{array}$ \\
\hline 25 & 25 & 7 & 70 & Tuntas & \\
\hline 26 & 26 & 4 & 40 & & $\begin{array}{c}\text { Tidak } \\
\text { Tuntas }\end{array}$ \\
\hline 27 & 27 & 3 & 30 & & $\begin{array}{c}\text { Tidak } \\
\text { Tuntas }\end{array}$ \\
\hline 28 & 28 & 7 & 70 & Tuntas & \\
\hline 29 & 29 & 5 & 50 & & $\begin{array}{c}\text { Tidak } \\
\text { Tuntas }\end{array}$ \\
\hline \multicolumn{2}{|c|}{ Jumlah Nilai } & 137 & 1370 & & \\
\hline \multicolumn{2}{|c|}{ Rata-Rata Nilai } & $\begin{array}{c}4,7 \\
2\end{array}$ & 47,24 & $\begin{array}{c}20,68 \\
\%\end{array}$ & $79,31 \%$ \\
\hline & $\begin{array}{l}\text { Tingkat } \\
\text { Ketuntasan }\end{array}$ & & & tuntas & $\begin{array}{c}\text { Tidak } \\
\text { Tuntas }\end{array}$ \\
\hline
\end{tabular}

\begin{tabular}{|c|c|c|c|c|c|}
\hline No & Responden & Skor & Nilai & Ket & Ket \\
\hline 1 & 01 & 7 & 70 & Tuntas & \\
\hline 2 & 02 & 5 & 50 & & $\begin{array}{c}\text { Tidak } \\
\text { Tuntas }\end{array}$ \\
\hline 3 & 03 & 6 & 60 & & $\begin{array}{c}\text { Tidak } \\
\text { Tuntas }\end{array}$ \\
\hline 4 & 04 & 4 & 40 & & $\begin{array}{c}\text { Tidak } \\
\text { Tuntas }\end{array}$ \\
\hline 5 & 05 & 5 & 50 & & $\begin{array}{c}\text { Tidak } \\
\text { Tuntas }\end{array}$ \\
\hline 6 & 06 & 2 & 20 & & $\begin{array}{c}\text { Tidak } \\
\text { Tuntas }\end{array}$ \\
\hline
\end{tabular}

Lebih jelasnya peningkatan hasil belajar siswa dapat dilihat dari nilai tes awal, pada gambar diagram batang di bawah ini : 


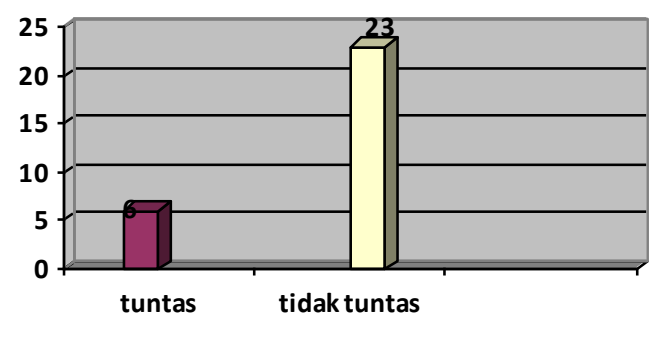

Grafik Hasil Belajar Siswa

Pada Tes Awal

Dari hasil observasi kegiatan siswa pada siklus I di atas terhadap tindakan yang dilakukan selama proses belajar mengajar berlangsung, yaitu siswa masih kurang aktif dalam proses pembelajaran.

Berdasarkan tes yang dilakukan, hasil belajar siswa belum memuaskan, karena tes dianggap berhasil apabila siswa mendapat nilai $\geq 65$. Hasil belajar siswa dapat dilihat pada tabel di bawah ini :

Tabel Hasil Belajar Siswa Pada Siklus I

\begin{tabular}{|c|c|c|c|c|c|}
\hline No & Responden & Skor & Nilai & Ket & Ket \\
\hline 1 & 01 & 9 & 90 & Tuntas & \\
\hline 2 & 02 & 8 & 80 & Tuntas & \\
\hline 3 & 03 & 7 & 70 & Tuntas & \\
\hline 4 & 04 & 5 & 50 & & $\begin{array}{c}\text { Tidak } \\
\text { Tuntas }\end{array}$ \\
\hline 5 & 05 & 8 & 80 & Tuntas & \\
\hline 6 & 06 & 6 & 60 & & $\begin{array}{c}\text { Tidak } \\
\text { Tuntas }\end{array}$ \\
\hline 7 & 07 & 7 & 70 & Tuntas & \\
\hline 8 & 08 & 8 & 80 & Tuntas & \\
\hline 9 & 09 & 10 & 100 & Tuntas & \\
\hline 10 & 10 & 5 & 50 & & $\begin{array}{c}\text { Tidak } \\
\text { Tuntas }\end{array}$ \\
\hline 11 & 11 & 6 & 60 & & $\begin{array}{c}\text { Tidak } \\
\text { Tuntas }\end{array}$ \\
\hline 12 & 12 & 5 & 50 & & $\begin{array}{c}\text { Tidak } \\
\text { Tuntas }\end{array}$ \\
\hline 13 & 13 & 5 & 50 & & $\begin{array}{c}\text { Tidak } \\
\text { Tuntas }\end{array}$ \\
\hline 14 & 14 & 4 & 40 & & $\begin{array}{c}\text { Tidak } \\
\text { Tuntas }\end{array}$ \\
\hline 15 & 15 & 3 & 30 & & \\
\hline
\end{tabular}

\begin{tabular}{|c|c|c|c|c|c|}
\hline 16 & 16 & 7 & 70 & Tuntas & \\
\hline 17 & 17 & 8 & 80 & Tuntas & \\
\hline 18 & 18 & 9 & 90 & Tuntas & \\
\hline 19 & 19 & 3 & 30 & & $\begin{array}{l}\text { Tidak } \\
\text { Tuntas }\end{array}$ \\
\hline 20 & 20 & 8 & 80 & Tuntas & \\
\hline 21 & 21 & 4 & 40 & & $\begin{array}{c}\text { Tidak } \\
\text { Tuntas }\end{array}$ \\
\hline 22 & 22 & 7 & 70 & Tuntas & \\
\hline 23 & 23 & 6 & 60 & & $\begin{array}{l}\text { Tidak } \\
\text { Tuntas }\end{array}$ \\
\hline 24 & 24 & 8 & 80 & Tuntas & \\
\hline 25 & 25 & 7 & 70 & Tuntas & \\
\hline 26 & 26 & 4 & 40 & & $\begin{array}{c}\text { Tidak } \\
\text { Tuntas }\end{array}$ \\
\hline 27 & 27 & 4 & 40 & & $\begin{array}{l}\text { Tidak } \\
\text { Tuntas }\end{array}$ \\
\hline 28 & 28 & 9 & 90 & Tuntas & \\
\hline 29 & 29 & 7 & 70 & Tuntas & \\
\hline \multicolumn{2}{|c|}{ Jumlah Nilai } & 187 & 1870 & & \\
\hline \multicolumn{2}{|c|}{ Rata-Rata Nilai } & 6,44 & 64,48 & $55,17 \%$ & $44,82 \%$ \\
\hline \multicolumn{2}{|c|}{$\begin{array}{c}\text { Tingkat } \\
\text { Ketuntasan }\end{array}$} & & & Tuntas & $\begin{array}{c}\text { Tidak } \\
\text { Tuntas }\end{array}$ \\
\hline
\end{tabular}

Dari tabel di atas, maka dapat diketahui bahwa siswa pada siklus I dari 29 siswa, sebanyak 13 siswa $(13 / 29 \times 100 \%) \quad 44,82 \% \quad$ belum mencapai tingkat ketuntasan belajar $(\geq 65)$. Sedangkan 16 siswa $(16 / 29 \times 100 \%) \quad 55,17 \% \quad$ yang mencapai tingkat ketuntasan. Nilai terendah 30, nilai tertinggi 100 dengan rata-rata nilai 64,48 . Tingkat ketuntasan klasikal 16/29x100\% = $55,17 \%$. Hal ini menunjukkan nilai siklus I siswa SDN 067252 Medan Deli belum tuntas mempelajari materi pelajaran menghargai keputusan bersama pada mata pelajaran PKn.

Lebih jelasnya peningkatan hasil belajar siswa dapat dilihat dari nilai tes siklus I, pada gambar diagram batang di bawah ini : 


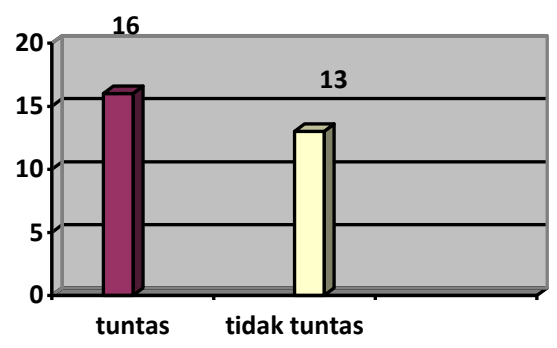

Grafik Hasil Belajar Siswa Pada Siklus I

Berdasarkan hasil observasi yang dilakukan, terjadi peningkatan aktifitas belajar siswa. Hal ini dapat dilihat dari lembar observasi kegiatan siswa pada siklus II masih melibatkan sebanyak 29 siswa yang terlihat secara umum sudah mulai serius dalam mengikuti proses belajar mengajar, aktif bertanya, dan sudah berani untuk mengungkapkan pendapatnya kepada orang lain.

Dari hasil observasi aktivitas siswa dalam siklus II dapat kita lihat kemajuan siswa sudah baik, semua siswa sudah ikut berperan aktif, berani untuk mengungkapkan pendapatnya kepada orang lain, mampu untuk menanggapi pendapat dari teman yang lain, dalam mengerjakan tugas yang diberikan oleh peneliti, siswa sudah lebih baik, cepat dalam menyelesaikannya, dan hasilnyapun sudah lebih meningkat dari pembelajaran siklus I.

Dari hasil tindakan yang dilakukan dan hasil tes dari siklus II diperoleh nilai hasil belajar siswa sudah mencapai tingkat ketuntasan belajar yang dapat kita lihat pada tabel di bawah ini :
Tabel Hasil Belajar Siswa Pada

Siklus II

\begin{tabular}{|c|c|c|c|c|c|}
\hline No & Responden & Skor & Nilai & Ket & Ket \\
\hline 1 & 01 & 10 & 100 & Tuntas & \\
\hline 2 & 02 & 9 & 90 & Tuntas & \\
\hline 3 & 03 & 9 & 90 & Tuntas & \\
\hline 4 & 04 & 8 & 80 & Tuntas & \\
\hline 5 & 05 & 8 & 80 & Tuntas & \\
\hline 6 & 06 & 7 & 70 & Tuntas & \\
\hline 7 & 07 & 9 & 90 & Tuntas & \\
\hline 8 & 08 & 8 & 80 & Tuntas & \\
\hline 9 & 09 & 10 & 100 & Tuntas & \\
\hline 10 & 10 & 8 & 80 & Tuntas & \\
\hline 11 & 11 & 7 & 70 & Tuntas & \\
\hline 12 & 12 & 8 & 80 & Tuntas & \\
\hline 13 & 13 & 7 & 70 & Tuntas & \\
\hline 14 & 14 & 7 & 70 & Tuntas & \\
\hline 15 & 15 & 6 & 60 & & $\begin{array}{l}\text { Tidak } \\
\text { Tuntas }\end{array}$ \\
\hline 16 & 16 & 8 & 80 & Tuntas & \\
\hline 17 & 17 & 9 & 90 & Tuntas & \\
\hline 18 & 18 & 9 & 90 & Tuntas & \\
\hline 19 & 19 & 5 & 50 & & $\begin{array}{l}\text { Tidak } \\
\text { Tuntas }\end{array}$ \\
\hline 20 & 20 & 8 & 80 & Tuntas & \\
\hline 21 & 21 & 7 & 70 & Tuntas & \\
\hline 22 & 22 & 8 & 80 & Tuntas & \\
\hline 23 & 23 & 8 & 80 & Tuntas & \\
\hline 24 & 24 & 9 & 90 & Tuntas & \\
\hline 25 & 25 & 9 & 90 & Tuntas & \\
\hline 26 & 26 & 8 & 80 & Tuntas & \\
\hline 27 & 27 & 7 & 70 & Tuntas & \\
\hline 28 & 28 & 9 & 90 & Tuntas & \\
\hline 29 & 29 & 8 & 80 & Tuntas & \\
\hline \multicolumn{2}{|c|}{ Jumlah Nilai } & 233 & 2330 & & \\
\hline \multicolumn{2}{|c|}{ Rata-Rata Nilai } & 8,03 & 80,34 & $93,10 \%$ & $6,89 \%$ \\
\hline \multicolumn{2}{|c|}{$\begin{array}{c}\text { Tingkat } \\
\text { Ketuntasan }\end{array}$} & & & Tuntas & $\begin{array}{l}\text { Tidak } \\
\text { tuntas }\end{array}$ \\
\hline
\end{tabular}

Dari tabel di atas, dapat dilihat bahwa siswa yang mencapai tingkat keberhasilan yang sesuai dengan standar ketuntasan belajar secara individu yaitu, nilai $\geq 65$ sebanyak 27 siswa (27/29x100\%) 93,10\% dari 29 siswa seluruh kelas $\mathrm{V}$, dengan rata-rata nilai keseluruhan yang diperoleh adalah sebesar 80,34. Dan dari tingkat ketuntasan belajar secara klasikal hasil belajar siswa 
juga telah tercapai, dengan ketetapan sebesar 80\%, siswa kelas V memperoleh ketuntasan belajar $93,10 \%$, maka upaya yang telah dilakukan untuk meningkatkan hasil belajar siswa dengan menggunakan metode diskusi telah berhasil.

Lebih jelasnya peningkatan hasil belajar siswa dapat dilihat dari nilai tes siklus II, pada gambar diagram batang di bawah ini :

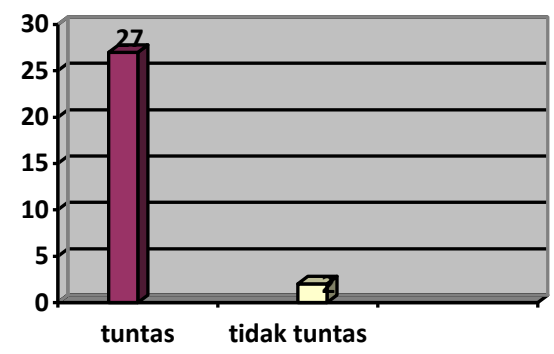

\section{Grafik Hasil Belajar Siswa Pada Siklus II}

Memasuki siklus II terjadi perubahan segala aktifitas belajar siswa. Siswa sudah berani bertanya dan mengungkapkan pendapatnya kepada orang lain apabila pendapatnya berbeda dengan yang lain, selain itu siswa juga sudah dapat bekerjasama dengan baik dalam menyelesaikan masalah yang telah diberikan oleh peneliti secara berdiskusi dengan teman kelompok. Dengan meningkatnya hasil belajar siswa, maka terbukti bahwa metode diskusi yang diterapkan pada penelitian ini dapat meningkatkan hasil belajar siswa.

Hasil belajar dari 29 siswa, terdapat 27 siswa $(27 / 29 \times 100 \%)$ 93,10\% yang masuk dalam kategori tuntas, dan sebanyak 2 siswa
$(2 / 29 \times 100 \%) \quad 6,89 \%$ yang tidak termasuk dalam kategori tuntas. Dengan tercapainya tingkat ketuntasan pada siklus II, maka proses belajar mengajar tidak lagi dilanjutkan pada siklus berikutnya.

\section{Pembahasan}

Berdasarkan hasil penelitian pada tes awal, maka dapat diketahui bahwa dari 29 siswa sebelum dilakukan pembelajaran pada mata pelajaran PKn materi pokok menghargai keputusan bersama, diperoleh sebanyak 23 siswa $(79,31 \%)$ belum mencapai tingkat ketuntasan belajar (nilai $\geq 65$ ), dan sebanyak 6 siswa $(20,68 \%)$ sudah mencapai tingkat ketuntasan, dengan nilai tertinggi 70 , terendah 20 , dan rata-rata nilai 47,24. Hal ini menunjukkan hasil tes awal siswa tergolong kategori rendah karena siswa kelas V SDN 067252 Medan Deli belum tuntas mempelajari pelajaran PKn khususnya materi pokok menghargai keputusan bersama.

Dari hasil penelitian siklus I, maka dapat diketahui bahwa nilai hasil belajar siswa dari 29 siswa, diperoleh sebanyak 13 siswa $(44,82 \%)$ belum mencapai tingkat ketuntasan belajar (nilai $\geq 65$ ), dan sebanyak 16 siswa $(55,17 \%)$ sudah mencapai tingkat ketuntasan belajar, dengan nilai tertinggi 100 , terendah 30 , dan rata-rata nilai 64,48 . Hal ini menunjukkan nilai siklus I siswa sudah mengalami peningkatan tetapi masih tergolong kategori rendah, dengan demikian dapat dikatakan 
bahwa kelas V SDN 067252 Medan

Deli belum tuntas mempelajari materi pelajaran menghargai keputusan bersama pada mata pelajaran PKn.

Dari hasil penelitian siklus II, maka dapat diketahui bahwa nilai hasil belajar siswa dari 29 siswa setelah dilakukan pembelajaran pada mata pelajaran PKn sebanyak 2 siswa $(6,89 \%)$ yang belum mencapai tingkat ketuntasan belajar (nilai $\geq 65$ ), dan sebanyak 27 siswa $(93,10 \%)$ sudah mencapai tingkat ketuntasan belajar, dengan nilai tertinggi 100 , terendah 50, dan rata-rata nilai 80,34. Hal ini menunjukkan nilai siklus II siswa sudah mengalami peningkatan dan tergolong tinggi, dengan demikian dapat dikatakan bahwa hasil belajar siswa kelas V SDN 067252 Medan Deli sudah mengalami ketuntasan dalam mempelajari materi pelajaran menghargai keputusan bersama pada mata pelajaran PKn.

\section{KESIMPULAN}

Berdasarkan hasil penelitian dan pembahasan dapat disimpulkan bahwa :

1. Nilai rata-rata siswa pada saat tes awal sebelum diberikan tindakan sebesar 47,24 dengan tingkat ketuntasan 20,68\% dan dinyatakan masih belum tuntas daalam belajar. Pada siklus I nilai rata-rata kelas meningkat 64,48 dengan tingkat ketuntasan belajar $55,17 \%$, kemudian pada siklus II nilai rata-rata kelas semakin meningkat menjadi 80,34, dengan tingkat ketuntasan belajar sebesar $93,10 \%$.

2. Hasil observasi kegiatan guru sikus I dengan jumlah skor adalah 54, dan rata-rata sebesar 3,00, dan pada hasil observasi kegiatan guru siklus II diperoleh skor 67, dan jika dirata-ratakan sebesar 3,72. Dari data yang telah disajikan terdapat peningkatan antara kegiatan guru siklus I dengan kegiatan guru siklus II terdapat peningkatan.

3. Hasil observasi kegiatan siswa siklus I diperoleh skor 26, dan rata-rata sebesar 1,44. Dan pada hasil observasi kegiatan siswa siklus II diperoleh skor 63, dan jika dirata-ratakan sebesar 3,50. Dari data yang telah disajikan terdapat peningkatan antara kegiatan siswa siklus I dengan kegiatan siklus II tardapat peningkatan.

Beberapa saran yang perlu disampaikan sebagai berikut :

1. Bagi guru PKn kelasV diharapkan untuk dapat menggunakan metode diskusi pada pokok bahasan menghargai keputusan bersama sehingga siswa dapat lebih aktif dalam mengikuti pembelajaran.

2. Bagi siswa diharapkan agar dapat mengikuti proses belajar mengajar dengan penggunaan metode diskusi pada pokok bahasan menghargai keputusan bersama dalam pelajaran PKn. 
DAFTAR RUJUKAN

Arikunto, Suharsimi. 2009. DasarDasar Evaluasi Pendidikan. Jakarta: Bumi Aksara.

Arikunto, Suharsimi. 2008. Penelitian Tindakan Kelas. Jakarta : Bumi Aksara.

Dewi, Rosmala. 2009. Penelitian Tindakan Kelas. Medan: CV. Dharma.

Dimyati, Mudjiono. 2006. Belajar dan Pembalajaran. Jakarta: Rineka Cipta.

Djamarah, Bahri. 2006. Strategi Belajar Mengajar. Jakarta: Rineka Cipta.

Hasibuan, J. 1993. Proses Belajar Mengajar. Bandung: Remaja Rosdakarya.

Hernawan, Asep. 2007. Pengembangan Kurikulum Dan Pembelajaran. Jakarta: Universitas Terbuka.

Sagala, Saiful. 2008. Konsep dan Makna Pembelajaran. Bandung: Alfabeta.

Sanjaya, Wina. 2008. Strategi Pembelajaran Berorientasi
Standar Proses pendidikan. Jakarta: Kencana.

Slameto. 2003. Belajar dan FaktorFaktor yang Mempengaruhinya. Jakarta: Rineka Cipta.

Sudjana, Nana. 1989. Penilaian Hasil Proses Belajar Mengajar. Bandung: PT. Remaja Rosda Karya.

Sujanto, Agus. 1996. Psikologi Perkembangan. Jakarta: Rineka Cipta.

Suryosubroto. 2009. Proses Belajar Mengajar di Sekolah. Jakarta: Rineka Cipta.

Syah, Muhibbin. 2003. Psikologi Belajar. Jakarta: PT Raja Grafindo Persada.

Thayeb, dkk. 2006. Pendidikan Kewarganegaraan Untuk SD Kelas V. Jakarta: Penerbit Erlangga. 